\title{
Clinical aspects of trace elements: Zinc in human nutrition - Zinc metabolism
}

\author{
Michelle M PluHATOR MSC, AlAN BR THOMSON MD PHD FRCPC FACP FRS FACC, RichARD N FEDORAK MD FRCPC
}

MM Pluhator, ABR THOMSON, RN FEDORAK. Clinical aspects of trace elements: Zinc in human nutrition - Zinc metabolism. Can J Gastroenterol 1995;9(6):327-332. Although zinc has been the most intensely studied trace element, much remains to be learned about its metabolism. Little is known about the normal mechanisms of absorption and transport across the intestinal tract. In addition, numerous unknowns surround the intricacies of bodily zinc homeostasis. Part two of this five-part review presents current views on the normal intestinal absorption, intracellular and extracellular metabolism, transport, excretion and homeostasis of zinc in the human body. The alterations in zinc metabolism that occur with age and changing physiological conditions are also discussed.

Key Words: Absorption, Intestinal transport, Metabolism, Trace element, Zinc

Aspects cliniques et métaboliques des éléments traces : le zinc dans la nutrition humaine

RÉSUMÉ : Bien que le zinc soit l'élément trace le plus étudié, beaucoup reste à découvrir au sujet de son métabolisme. On en sait relativement peu sur son mode d'absorption et son transport normaux dans les voies digestives. De plus, de nombreuses inconnues entourent les relations complexes de l'homéostasie du zinc dans l'organisme. Dans la deuxième partie de cette série de cinq articles, nous passerons en revue l'opinion actuelle sur l'absorption intestinale, le métabolisme intra- et extra-cellulaire, le transport, l'excrétion et l'homéostasie du zinc dans l'organisme humain. Les altérations qui affectent le métabolisme du zinc en fonction de l'âge et de l'état de santé physiologique sont également abordées.

$\mathrm{T}$ HIS REVIEW IS THE SECOND OF A five-part series that examines zinc in terms of its biochemistry and physiology, metabolism, dietary require-

ments, nutritional assessment and states of excess and deficiency.

Although zinc has been the most intensely studied trace element, much re-

\footnotetext{
Division of Gastroenterology, Department of Medicine, University of Alberta, Edmonton, Alberta

Correspondence: Dr RN Fedorak, Division of Gastroenterology, Department of Medicine, University of Alberta, 519 Robert Newton Research Building, Edmonton, Alberta T6G 2C2.

Telephone 403-492-6941, fax 403-492-3744, e-mail: richard.fedorak@ualberta.ca

Received for publication August 16, 1994. Accepted January 23, 1995
}

mains unknown about its metabolism. Little is known about its absorption and transport across the intestinal tract. Additionally, the control mechanisms that allow the body to regulate its zinc content and absorption are poorly understood. This review presents an overview of what is currently known about the normal intestinal absorption, intracellular and extracellular metabolism, transport, excretion and homeostasis of zinc in the human body. The alterations in zinc metabolism that occur with age and changing physiological conditions are also highlighted.

\section{INTESTINAL ABSORPTION OF ZINC}

Absorption of zinc is thought to occur throughout the small intestine (1). Although the highest rate of zinc absorption appears to occur in the jejunum, the duodenum is the first segment exposed to zinc postprandially, and it may thus serve as the primary site for quantitative zinc absorption (1).

Investigators presume that intestinal absorption of zinc is aided by ligands. In the intestinal lumen zinc is likely matched to a ligand with an affinity for this element. The digestion of food leads to the introduction of amino acids, pancreatic secretions, organic acids, phosphates and other cations capable of associating with zinc into the intestinal lumen (2-4). The resultant complexes are then presented to the surface of the mucosal cell. 


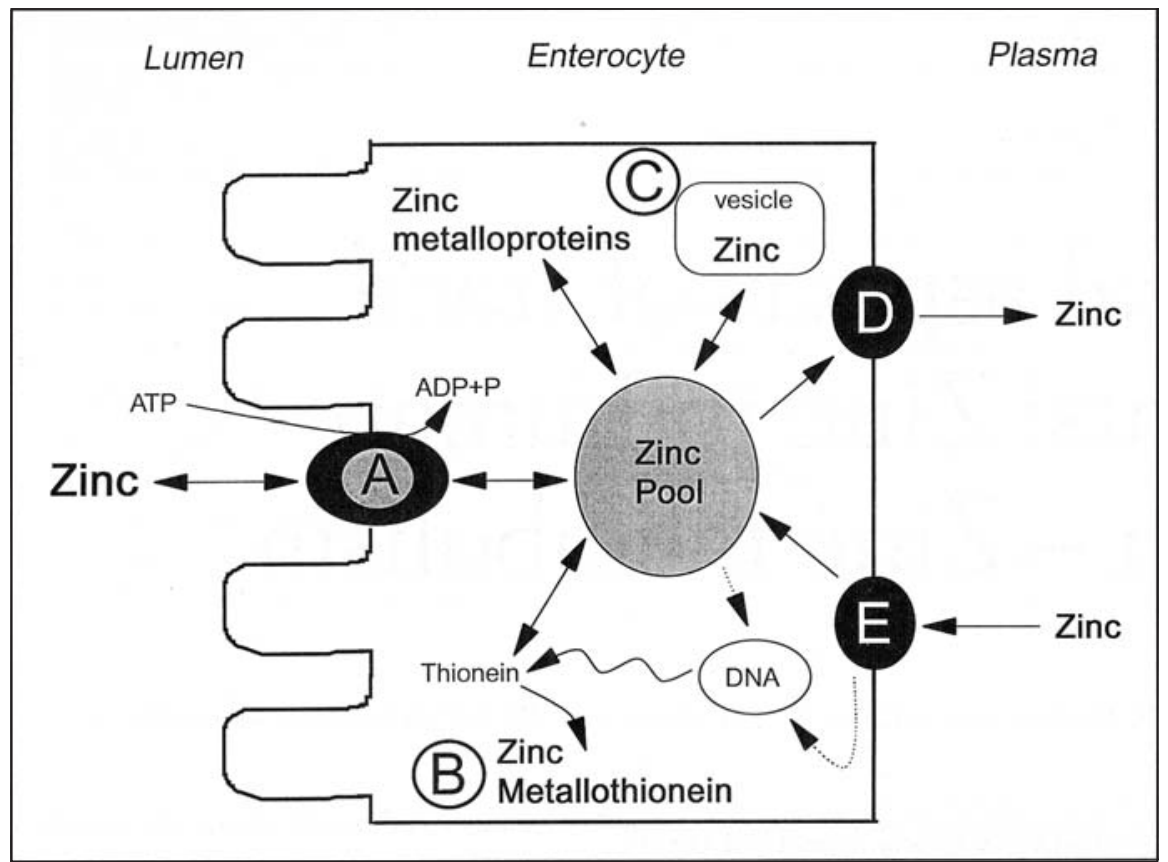

Figure 1) Dietary zinc is transported across the intestinal lumen (A). Newly absorbed zinc is bound by metallothionein and stored (B), used in cell metabolism (C) or released to the plasma (D). When dietary zinc is elevated, plasma zinc and thionein synthesis increase (dashed lines). A large quantity of zinc entering the intestinal cell from the plasma becomes bound to metallothionein (E). Adapted from reference 7

As the intraluminal zinc complexes approach the enterocytes lining the intestinal mucosa, they contact the glycocalyx covering of the brush border membrane. Few studies have assessed the role of the glycocalyx in zinc absorption. However, two potential scenarios have been proposed: zinc is released from the luminal complexes because of a greater affinity for some surface groups of the glycocalyx; or zinc complexes attach to the glycocalyx and are transported across the mucous layer intact (5).

Events at the surface of the brush border membrane have not been fully defined. Using triple-lumen steady state perfusion technology, researchers have found that, over the range of 0.1 to $1.8 \mathrm{mM}$ of zinc, the rate of zinc absorbed is proportional to the amount infused (1). The rate of zinc absorption plateaus with higher concentrations, suggesting a saturable transport mechanism. Additionally, that study investigated the relationship between the intestinal absorption of zinc and that of glucose and sodium. A 'symport' phenomenon was found for zinc and glucose absorption (ie, zinc and glucose interact with a common carrier), while an 'antiport' effect was exerted on sodium absorption (ie, zinc decreases intestinal absorption of sodium, and at high concentrations may even cause a net excretion of sodium). Human intestinal zinc absorption is, therefore, likely to be a carrier-mediated transport process.

Intracellularly, a flux of zinc from mucosa to serosa and from serosa to mucosa appears to be in progress at all times (6). Zinc entering the enterocyte equilibrates with the intracellular zinc pool and can be bound by metallothionein and stored until mature cells are sloughed off, used in the metabolism of the absorbing cell or passed through the serosal border to be picked up by the portal bloodstream $(4,7)$ (Figure 1).

A key role for metallothionein, a sulphur-rich metal-binding protein, in zinc homeostasis was first suggested by Richards and Cousins (8). The authors hypothesized that when metallothionein was synthesized inside the intestinal cell, it could trap zinc and make it unavailable for transfer to the circulating plasma. The amount of metallothionein present in the mucosa was found to be negatively correlated to zinc absorption, thereby exercising homeostatic control of zinc metabolism. Other reports do not support this concept. Jackson et al (9) refuted the earlier hypothesis when they gave ${ }^{65} \mathrm{Zn}$ by gavage to rats and followed the distribution of radioisotope over time. They found that both control and zinc-depleted rats retained the same amount of ${ }^{65} \mathrm{Zn}$ in the intestinal wall, even though more ${ }^{65} \mathrm{Zn}$ appeared in the carcasses of the zinc-depleted rats. When large amounts of zinc were injected intraperitoneally, zinc absorption decreased after 6 to $24 \mathrm{~h}$, possibly because of the synthesis of metallothionein. Subsequent studies by Cousins (10) have shown that relatively large quantities of zinc are needed to induce metallothionein production, and this event is not likely to happen under physiological levels.

\section{SYSTEMIC TRANSPORT OF ZINC}

Approximately $50 \%$ of zinc in the plasma is freely exchangeable and loosely bound to albumin; $7 \%$ is bound to amino acids such as histidine and cysteine, and the remainder is bound to macroglobulins and other serum proteins $(2,11)$. Alphaz-macroglobulin comprises a tightly bound pool of plasma zinc. The metabolic fate and the physiological significance of zinc circulating with this protein are not clear. Because it is an acute-phase protein that is induced during inflammation, alphaz-macroglobulin's zinc-binding capacity may be related to host immune functions (12). A small portion of zinc, about 0.1 to $0.2 \%$ of total plasma zinc, is ultrafilterable (12). Ultrafilterable zinc could act as a donor for a high affinity, cellular zinc transport system, or it could represent an intermediate state between protein-bound zinc and that marked for cell uptake (12).

Plasma is the major route of zinc transportation within the body. The plasma's zinc content is approximately $1 \mu \mathrm{g} / \mathrm{mL}$, and in most tissues ranges from 11 to $150 \mu \mathrm{g} / \mathrm{g}$ (13). It is, therefore, obvious that an active or facilitated uptake of zinc by all tissues must occur, but little is known about this 
process. Even less is known about the transportation of zinc out of the tissues into the plasma. Certain tissues (eg, gastrointestinal mucosal cells) secrete zinc as part of their normal physiological function. It also appears that a turnover of zinc in other tissues results in a loss of zinc from the cells via unknown mechanisms. It is certain, however, that a constant renewal/exchange system is required to maintain sufficient levels of cellular zinc (10).

Under conditions of catabolism, loss of zinc from the tissues may be excessive. For example, during periods of muscle catabolism, a large loss of zinc from skeletal muscle results in increased urinary and fecal excretion of zinc (13). This elevated urinary zinc may be related to the loss of peptides and amino acids from the muscle during breakdown, which could increase the ultrafilterable 'pool' of zinc in plasma. Another possible explanation is that zinc could be associated with myoglobin and thus be lost as a result of the myoglobinuria that accompanies severe muscle breakdown (13).

Approximately 30 to $40 \%$ of the zinc that enters the hepatic venous supply is removed by the liver, from which it is subsequently released back into the blood (14). Circulating zinc is incorporated at differing rates into various extrahepatic tissues, all of which have different rates of zinc turnover. Uptake of zinc by the central nervous system and the bones is relatively slow, and this zinc remains firmly bound for long periods. Zinc is incorporated in the hair and thus becomes unavailable to the tissues. The most rapid accumulation and turnover of zinc occurs in the pancreas, liver, kidney and spleen (14). Uptake and exchange of zinc by red cells and muscle is much slower.

The kinetics of zinc absorption and elimination follow a two-component model. The initial rapid phase has a half-life in humans of 12.5 days, and the slower pool turns over with a halflife of approximately 300 days (14). The latter pool appears to include most of the skeletal muscle zinc. Zinc entering the plasma is cleared within hours, largely through entry into the blood

TABLE 1

Zinc balance

\begin{tabular}{lccc}
\hline & Amount & Percentage of intake & Reference \\
\hline Intake & 10 to $15 \mathrm{mg} /$ day & & \\
Absorption & 3 to $5 \mathrm{mg} /$ day & 30 & 2 \\
Excretion & & & \\
Feces & 9.0 to $14.0+\mathrm{mg} /$ day $^{\star}$ & 90 & 14 \\
Urine & 0.3 to $0.5 \mathrm{mg} /$ day & 2 to 10 & 14 \\
Sweat & 0.4 to $2.8 \mathrm{mg} /$ day $^{\dagger}$ & Variable & 22 \\
Semen & $0.6 \mathrm{mg} /$ ejaculum & Variable & 22 \\
Menses & 0.005 to $0.015 \mathrm{mg}_{\text {day }}^{\dagger}$ & Negligible & 29 \\
\hline
\end{tabular}

*Upper limit for fecal zinc excretion based upon excess dietary plus endogenous excretion; ${ }^{\dagger}$ Seminal zinc

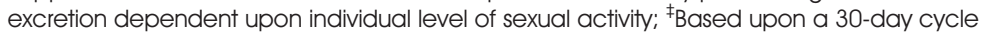

cells and tissues rather than by excretion from the body.

The major organ involved in zinc metabolism is the liver. The liver cytosol of humans and other mammals contains zinc-binding components of differing molecular weight and lability, the amounts and proportions of which vary with the zinc nutritional status and age of the animal or human (14). When the liver zinc content is increased above normal levels $(30 \mu \mathrm{g} / \mathrm{g}$ wet weight), the additional zinc is associated mainly with metallothionein. Short term fluctuations in metallothionein-bound zinc levels could be directly related to daily variations in zinc intake (15).

\section{ZINC EXCRETION}

Given normal dietary circumstances, the feces are the major route of zinc excretion. A healthy human adult whose zinc balance is in equilibrium, and who ingests 10 to $15 \mathrm{mg}$ zinc/day, excretes approximately $90 \%$ of this amount in the feces, with 2 to $10 \%$ excreted in the urine (16). Fecal excretion includes the excretion of both unabsorbed dietary zinc and endogenous zinc. The level of excretion of endogenous zinc in the feces varies according to the balance between true absorption and metabolic needs. This variation is one of the primary mechanisms for maintaining zinc homeostasis (14). Weigand and Kirchgessner (17) demonstrated that the endogenous fecal zinc excretion of rats on a zinc depletion diet was so low that it was exceeded by urinary zinc losses, which are not affected by dietary zinc intake in the rat. An increase in endogenous fecal excretion that correlates positively with dietary zinc increases has been demonstrated in the human (18). The actual amount of endogenous zinc lost from the human body in the feces may range from less than $1 \mathrm{mg}$ to several milligrams daily (14) (Table 1).

Endogenous fecal losses of zinc arise when zinc is secreted from the body into the gut and is not subsequently absorbed. Matseshe et al (19) used a marker perfusion technique to measure the intraluminal quantities of zinc in the gastrointestinal tract of healthy adult men who consumed different test meals. Over the $5 \mathrm{~h}$ following the meal, between 144 and $300 \%$ of the amount of zinc ingested was recoverable through aspiration done at the ligament of Treitz. The source of this additional zinc (2.2 to $4.8 \mathrm{mg}$ ) was the meal-stimulated secretion of pancreatic fluid. The researchers concluded that an enteropancreatic circulation existed in humans. The pancreatic output of zinc (which is six times greater than that of bile) is the largest source of endogenous mineral re-excretion into the intestinal lumen (6). Much of this zinc must eventually be resorbed to avoid a negative zinc balance.

The proportion of a dose of ${ }^{65} \mathrm{Zn}$ that subsequently appeared in pancreatic, biliary and gastroduodenal secretions in human subjects was not enough to account for the total excreted in the feces (14). It was discovered that the other major pathway of zinc excretion is provided by the intestinal mucosal cells. Zinc within these mucosal cells may include unabsorbed zinc taken up from the intestinal lumen and zinc re-entering the cells from the 
plasma under conditions of net efflux from the serosal surface to the lumen. Intestinal metallothionein synthesis, which is sensitive to the body's zinc status, may enhance the value of this route of excretion to the overall process of homeostatic control of zinc levels (14).

The amount of zinc excreted in the urine of healthy adults is about 0.3 to $0.5 \mathrm{mg} /$ day (14) (Table 1). Relatively high urinary zinc excretion rates occur in both term and premature infants, but by two months of age these rates are down to 0.01 to $0.02 \mathrm{mg}$ zinc/ $/ \mathrm{kg}$ body weight/day (20). Young children aged 33 to 90 months excrete a mean of $0.187 \pm 0.097 \mathrm{mg} / 24 \mathrm{~h}$ (21). In adults, the amount of zinc excreted in the urine varies with the level of intake. In the case of adult men who consumed a severely zinc-deficient experimental diet $(0.28 \mathrm{mg} /$ day $)$, urinary zinc was decreased threefold to $0.14 \mathrm{mg} /$ day (22).

Urinary zinc arises largely from the ultrafilterable portion of plasma zinc (23). Net reabsorption of up to $95 \%$ of filtered zinc under basal conditions occurs in the distal parts of the renal tubule (23). The amount of zinc excreted correlates with the rate of urine (volume) production and creatinine excretion (24). The modest increases in urinary zinc output seen during pregnancy may thus be due to increased tubular flow rates. In parenterally fed infants, little stool is passed; therefore urinary loss becomes the main route for zinc excretion. Eighty-seven per cent of zinc excretion occurs in the urine of parenterally fed infants compared with $8 \%$ in healthy breast-fed infants (20). Adults supported by total parenteral nutrition likewise show increased urinary zinc excretion $(25,26)$. This change may partially be explained by the low fecal output of these patients. Additionally, experimental studies done on various total parenteral nutrition solutions and single amino acid infusions have confirmed that infused amino acids, particularly cysteine and histidine, are potent stimulators of renal zinc excretion (20). Causes of increased zincuria may include an increase in the ultrafilterable portion of plasma zinc and the prevention of zinc resorption through its being bound to amino acids secreted into the renal tubule (23).

Healthy adults living in a temperate North American climate have been reported to lose from 0.4 to $2.8 \mathrm{mg}$ of zinc daily in sweat (22). Studies have reported that whole body sweat losses are related to dietary intake. When intakes of zinc were $8.3 \mathrm{mg} /$ day, young men lost an average of $0.5 \mathrm{mg}$ zinc in sweat daily; losses were reduced to $0.24 \mathrm{mg} /$ day on a marginal zinc intake and increased to $0.62 \mathrm{mg} /$ day when subjects were repleted with a zinc intake of $34 \mathrm{mg} /$ day (27). This reduction of sweat losses during times of dietary deficiency may represent a mechanism for the conservation of zinc. Normal sweat contains $1.15 \pm 0.03 \mu \mathrm{g} z \mathrm{inc} / \mathrm{mL}$, approximately $75 \%$ of which is in the cell-free portion, with the remainder associated with desquamated epithelial cells (28).

Menstrual losses of zinc are negligible, with average losses of between 0.1 and $0.5 \mathrm{mg}$ zinc occurring per period (29). This represents a loss of about 0.005 to $0.015 \mathrm{mg} /$ day over a typical 30 -day cycle, which is a minute fraction of the normal zinc intake.

Despite the high concentrations of zinc found in the prostate and prostatic secretions, very few experiments have investigated seminal zinc losses in men. Baer and King (22) found that seminal zinc losses were roughly comparable with the amounts lost daily in sweat and urine, and were responsible for $20 \%$ of the total endogenous zinc losses experienced by their subjects. One seminal emission increased the loss by $0.6 \mathrm{mg} /$ ejaculum/day. The amount of zinc lost via this route was quite variable within and among individuals. In addition, losses depend on the individual level of sexual activity.

\section{ZINC HOMEOSTASIS}

The relatively constant levels of zinc found in the body, even though intake varies greatly over time, suggest that an efficient mechanism for whole body homeostasis exists. Homeostasis is maintained by control of gastrointestinal absorption and bodily excretion of zinc. Higher absorption in cases of lower body zinc load and increased excretion during times of high zinc intake both contribute to zinc homeostasis. Although changes in urinary zinc output contribute little to the maintenance of whole body homeostasis given normal dietary intakes, during times of overt zinc depletion, a major decrease in the urinary zinc output occurs (30).

An increase in zinc absorption rates is a well-described gastrointestinal response to a diet low in zinc, but decreases in the rate of gastrointestinal zinc excretion are also known to occur in response to such a diet (22). In contrast, an increase in dietary zinc intake results in both a reduced fractional absorption of zinc and an increase in the gastrointestinal excretion of zinc (31).

When these primary homeostatic mechanisms are not sufficient to handle large dietary reductions or excesses of zinc, a second line of defence enters. A large excess of zinc leads to tremendous losses via nonphysiological routes (eg, hair) (13), while a highly zincdeficient diet causes a selective loss of zinc from certain body fluids and tissues (13). Animal studies have shown that plasma zinc levels can drop rapidly after the introduction of a low zinc diet (32) and that liver zinc levels reflect recent dietary intakes (33). However, tissues that show symptoms of acute zinc deficiency (eg, skin, hair and gut) show little initial change in their total zinc content. The rapid fall in plasma zinc levels that follows the introduction of a diet low in zinc may be part of a homeostatic mechanism developed to support preferentially zinc maintenance in tissues susceptible to deficiency symptoms (13). In much the same way, the preferential removal of surplus zinc through incorporation into the hair is likely a method of preventing damage to other tissues.

The mucosal cell appears to play an important role in zinc homeostasis. Mucosal uptake of zinc occurs via two processes: a nonsaturable process not affected by dietary zinc intake, and a saturable process stimulated by zinc depletion. Results of studies of weanling rats provided with a range of dietary zinc from 5.6 to $141 \mathrm{mg} / \mathrm{kg}$ showed that, even though zinc intake rose line- 
arly, true absorption, apparent absorption and apparent retention each plateaued at about the $40 \mathrm{ppm}$ level (17). At the lowest dietary intakes, a quantitative (100\%) absorption of dietary zinc takes place, and fecal zinc is derived entirely from endogenous losses. However, at higher levels of zinc intake, a decrease in true absorption and an increase in endogenous excretion into the gut combine to provide stable bodily retention. Studies of in situ ligated loops of rat intestine infused with zinc concentrations ranging from 1 to $200 \mu \mathrm{g} / \mathrm{mL}$ have displayed saturation kinetics suggestive of a carrier-mediated function (34). Further, at the lower end of zinc infusion levels (1 to $50 \mu \mathrm{g} / \mathrm{mL}$ ), mucosal binding took place at specific sites; beyond this range, binding was not specific. Thus, absorption occurs via a saturable process: above a certain level, the capacity of this process is exceeded. Excretion of zinc is the main regulator of zinc homeostasis at higher dietary zinc intake levels (35).

\section{CHANGES IN ZINC METABOLISM WITH AGE AND PHYSIOLOGICAL CONDITIONS}

Recommended intake levels of zinc are highest for infants and for pregnant and lactating women. These higher levels take into account the increased demands for zinc experienced by the growing fetus and infant; milk production also requires an increased zinc supply. However, there is also a possibility that the efficiency of intestinal zinc absorption is increased during these times of rapid growth and production. Studies by Davies and Williams (36) on pregnant rats found that the absorptive capacity of the small intestine increased during periods of pregnancy and lactation. Zinc absorption per duoREFERENCES

1. Lee HH, Prasad AS, Brewer GJ,

Owyang C. Zinc absorption in human small intestine. Am J Physiol 1989;256:G87-91.

2. Guthrie HA. Micronutrient elements. In: Bagby RS, ed. Introductory Nutrition, 7th edn. Toronto: Times Mirror/Mosby College Publishing, 1989:289-335.

3. Lonnerdal B, Keen CL, Hurley LS. Zinc binding ligands and complexes in denal loop was found to increase after the 12th day of pregnancy and to continue to rise during lactation. During the latter part of pregnancy, zinc absorption was found to increase specifically (ie, in contrast to a general increase in nutrient absorption), probably to meet the increased needs of the fetus because maternal zinc retention levels were unchanged. Mucosal hypertrophy was responsible for the general increase in nutrient absorption, including zinc, during lactation. Swanson et al (37), using stable isotopes, found no significant difference in the zinc absorption of pregnant and nonpregnant women. It is possible that a small increase in zinc absorption rates during human pregnancy may be sufficient to store enough zinc to cover the needs of the fetus, while the rat, with its many fetuses and short pregnancy term, may require a much faster zinc accrual rate (5).

Little information is available on the effect of ageing on zinc metabolism in humans. It is, however, well known that the newborn animal absorbs zinc to a higher degree than does the older animal (17). Studies done on rats of different ages suggested that the transport system displayed a higher affinity for zinc at a young age. Total zinc uptake was shown to increase with age, and values were higher for younger versus adult rats. Another study showed that the intestinal absorption of ${ }^{65} \mathrm{Zn}$ decreases with age in rats (38). In humans, the retention of zinc with age has been reported (39). The values for zinc balances reported for children and young adults, compared with zinc balances of older persons, indicate that zinc metabolism changes with age (40). Decreases in both plasma and tissue levels of zinc have been reported, mainly in individuals with pathological zinc metabolism. Adv Nutr Res 1984;6:139-67.

4. Solomons NW. Factors affecting the bioavailability of zinc. J Am Diet Assoc 1982;80:115-21.

5. Lonnerdal B. Intestinal absorption of zinc. In: Mills CF, ed. Zinc in Human Biology. London: Springer-Verlag, 1989:33-55.

6. Solomons NW. Biological availability of zinc in humans. Am J Clin Nutr 1982;35:1048-75. conditions. However, these persons are usually older individuals. As ageing and various disease states may both affect zinc status, it becomes important to be able to distinguish between the effects of the two variables. Very little information exists on zinc metabolism in the older adult population. Among the parameters of zinc metabolism that may possibly change with age are intestinal absorption of zinc, endogenous excretion, tissue retention and zinc balance, plasma levels and exchangeable zinc pool status. Should it be possible to distinguish significant changes in zinc metabolism associated with age, corrective measures may aid in reversing these changes; such corrective measures may also prevent the development of disease states in which abnormal zinc statuses are involved.

\section{CONCLUSIONS}

Although medical researchers have a more comprehensive understanding of the role of zinc in human nutrition and homeostasis than they do for any other trace element, there is a considerable lack of knowledge about normal zinc metabolism and the metabolic sources of the pathological changes that occur during times of zinc deficiency. The relatively constant control exerted over zinc levels in the tissues and body fluids, maintained even with diverse dietary intakes, suggests that efficient mechanisms work to control whole body homeostasis. Investigation of the factors responsible for these adaptive controls will likely provide long-anticipated insights into the complexities of zinc metabolism, including the ways in which human physiological processes change as the human body ages, and faces the challenges of pregnancy, growth and disease.

7. Cousins RJ. Regulation of zinc absorption: role of intracellular ligands. Am J Clin Nutr 1979;32:339-45.

8. Richards MP, Cousins RJ. Mammalian zinc homeostasis: requirements for RNA and metallothionine synthesis. Biochem Biophys Res Commun 1975;64:1215-23.

9. Jackson MJ, Jones DA, Edwards RHT. Zinc absorption in the rat. Br J Nutr 1981;46:15-27.

10. Cousins RJ. Absorption, transport and 
hepatic metabolism of copper and zinc: special reference to metallothionine and ceruloplasmin. Physiol Rev 1985;65:238-309.

11. Gordon EF, Gordon RC, Passal DB. Zinc metabolism: basic, clinical, and behavioral aspects. J Pediatr 1981;99:341-9.

12. Cousins RJ. Systemic transport of zinc. In: Mills CF, ed. Zinc in Human Biology. London: Springer-Verlag, 1989:79-93.

13. Jackson MJ. Physiology of zinc: general aspects. In: Mills CF, ed. Zinc in Human Biology. London: Springer-Verlag, 1989:1-14.

14. Hambidge KM, Casey CE, Krebs NF. Zinc. In: Mertz W, ed. Trace Elements in Human and Animal Nutrition, 5th edn. Toronto: Academic Press Inc, 1986:1-137.

15. Cousins RJ. Regulatory aspects of zinc metabolism in liver and intestine. Nutr Rev 1979;37:97-103.

16. Swanson CA, King JC. Zinc utilization in pregnant and nonpregnant women fed controlled diets providing the zinc RDA. J Nutr 1982;112:697-707.

17. Weigand E, Kirchgessner M. Total true efficiency of zinc utilization: determination and homeostatic dependence upon zinc supply status in young rats. J Nutr 1980;110:469-80.

18. Jackson MJ, Jones DA, Edwards RHT, Swainbank IG, Colman NL. Zinc homeostasis in man: studies using a new stable isotope dilution technique. Br J Nutr 1984;51:199-208.

19. Matseshe JW, Phillips SF, Malagelada JR, McCall JT. Recovery of dietary iron and zinc from the proximal intestine of healthy man: studies of different meals and supplements. Am J Clin Nutr 1980;33:1946-53.

20. Zlotkin SH. Assessment of trace element requirements (zinc) in newborns and young infants, including the infant born prematurely. In: Chandra RK, ed. Trace Elements in Nutrition of Children - II. New York: Raven Press, 1991:49-64.

21. Hambidge KM, Chavez MN, Brown RM, Walravens PA. Zinc nutritional status of young middle-income children and effects of consuming zinc fortified breakfast cereals. Am J Clin Nutr 1979;32:2532-9.

22. Baer MT, King JC. Tissue zinc levels and zinc excretion during experimental zinc depletion in young men. Am J Clin Nutr 1984;39:556-70.

23. Abu-Hamdan DK, Migdal SD, Whitehouse R, Rabbani P, Prasad AS, McDonald FD. Renal handling of zinc: effect of cysteine infusion. Am J Physiol 1981;241:F487-94.

24. Canfield WK, Hambidge KM, Johnson L. Predicting $24 \mathrm{~h}$ zinc excretion using fractional urine collections. Am J Clin Nutr 1982;35:842. (Abst)

25. Wolman SL, Anderson GH, Marliss EB, Jeejeebhoy KN. Zinc in total parenteral nutrition: requirements and metabolic effects. Gastroenterology 1979;76:458-67.

26. Takagi Y, Okada A, Stakura T, Kawashima Y. Clinical studies on zinc metabolism during total parenteral nutrition as related to zinc deficiency. JPEN 1986;10:195-202.

27. Milne DB, Canfield WK, Mahalko JR, Sandstead HH. Effect of oral folic acid supplements on zinc, copper and iron absorption and excretion. Am J Clin Nutr 1984;39:535-9.

28. Prasad AS, Schulert AR, Sandstead $\mathrm{HH}$, Miale A, Farid Z. Zinc, iron, and nitrogen content of sweat in normal and deficient subjects. J Lab Clin Med 1963;62:84-9.

29. Hess FM, King JC, Margen S. Zinc excretion in young women on low zinc intakes and oral contraceptive agents. J Nutr 1977;107:1610-20.

30. Nelder KH, Hambige KM. Zinc therapy of acrodermatitis enteropathica. NJ Med 1975;292:879-82.

31. Jackson MJ, Jones DA, Edwards RHT, Swainbank IG, Colman NL. Zinc homeostasis in man: studies using a new stable isotope dilution technique. Br J Nutr 1984;51:199-208.

32. Wilkins PJ, Grey PC, Dreosti IE. Plasma zinc as an indicator of zinc status in rats. Br J Nutr 1972;26:113-20.

33. Underwood EJ. Trace Elements in Human and Animal Nutrition, 4th edn. New York: Academic Press, 1977.

34. Davies NT. Studies on the absorption of zinc by rat intestine. $\mathrm{Br} J$ Nutr 1980;43:189-203.

35. Coppen DE, Davies NT. Studies on the effect of dietary zinc dose on ${ }^{65} \mathrm{Zn}$ absorption in vivo and on the effects of zinc status on ${ }^{65} \mathrm{Zn}$ absorption and body loss in young rats. Br J Nutr 1987;57:35-44.

36. Davies NT, Williams RB. The effect of pregnancy and lactation on the absorption of zinc and lysine by the rat duodenum in situ. Br J Nutr 1977;38:417-23.

37. Swanson CA, Turnlund JR, King JC. Effect of dietary zinc sources and pregnancy on zinc utilization in the adult woman fed controlled diets. J Nutr 1983;113:2557-67.

38. Methfessel AH, Spencer H. Effect of age and protein intake on ${ }^{65} \mathrm{Zn}$ excretion and tissue distribution in the rat. Radiat Res 1970;43:237.

39. Widdowson EM. Chemical analysis of the body. In: Brokez J, ed. Human Body Composition. Oxford: Pergamon, 1965:31-47.

40. Spencer H, Osis D, Kramer L, Norris C. Intake, excretion, and retention of zinc in man. In: Prasad AS, ed. Trace Elements in Human Health and Disease. New York: Academic Press, 1976:345-61. 


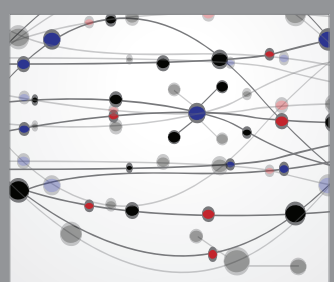

The Scientific World Journal
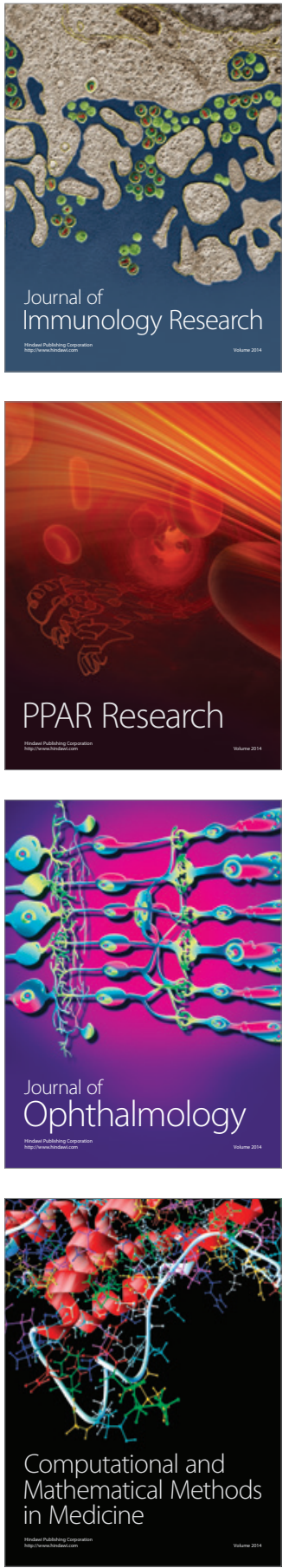

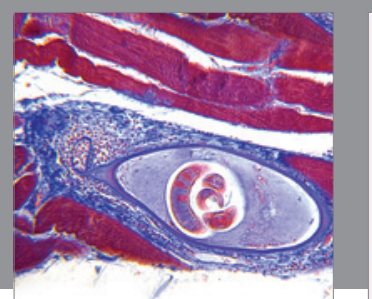

Gastroenterology Research and Practice

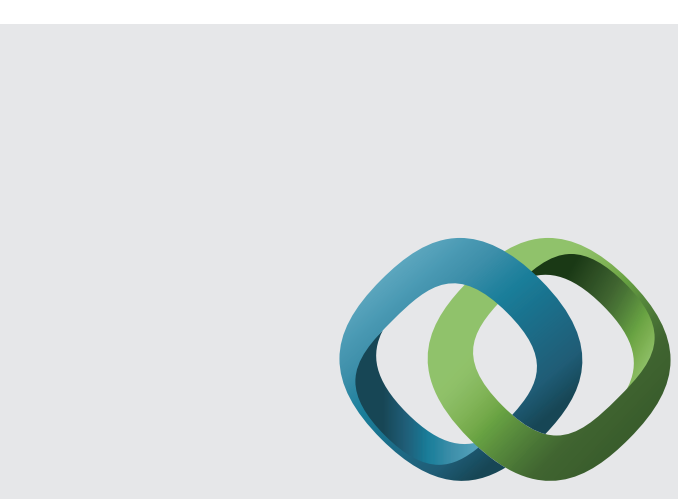

\section{Hindawi}

Submit your manuscripts at

http://www.hindawi.com
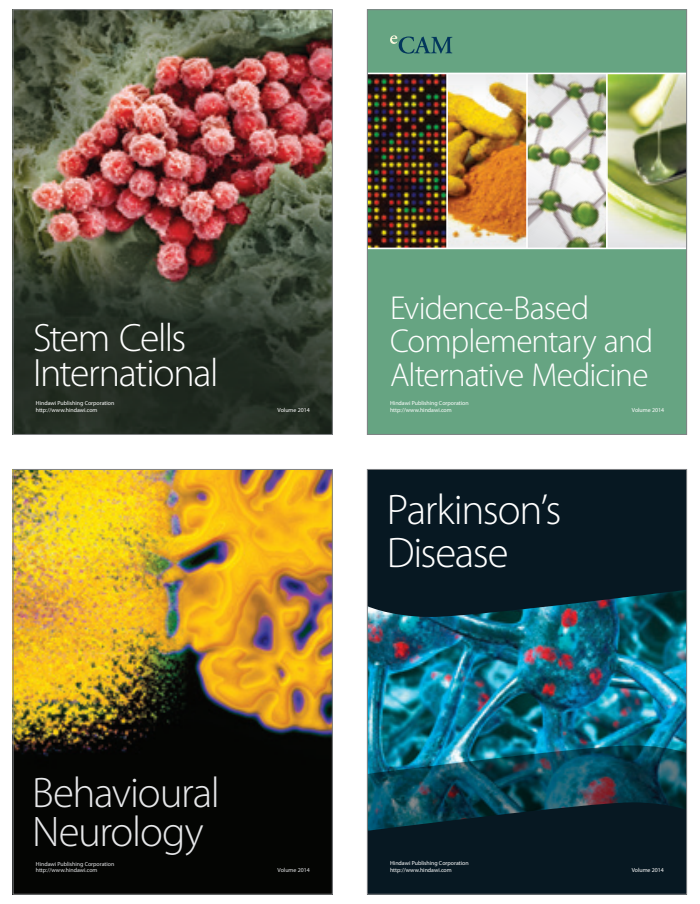
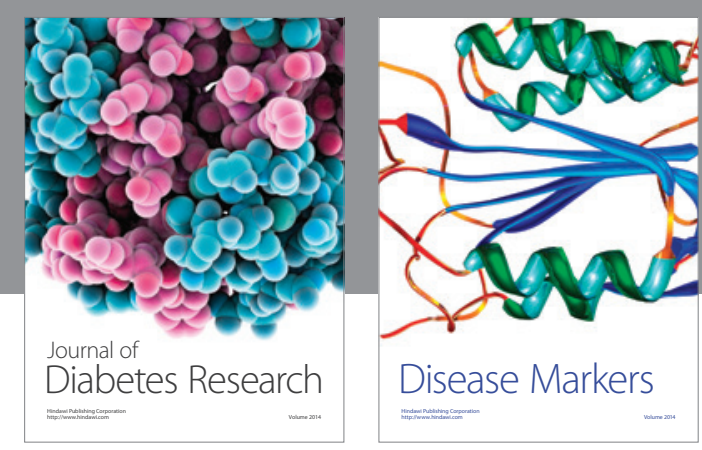

Disease Markers
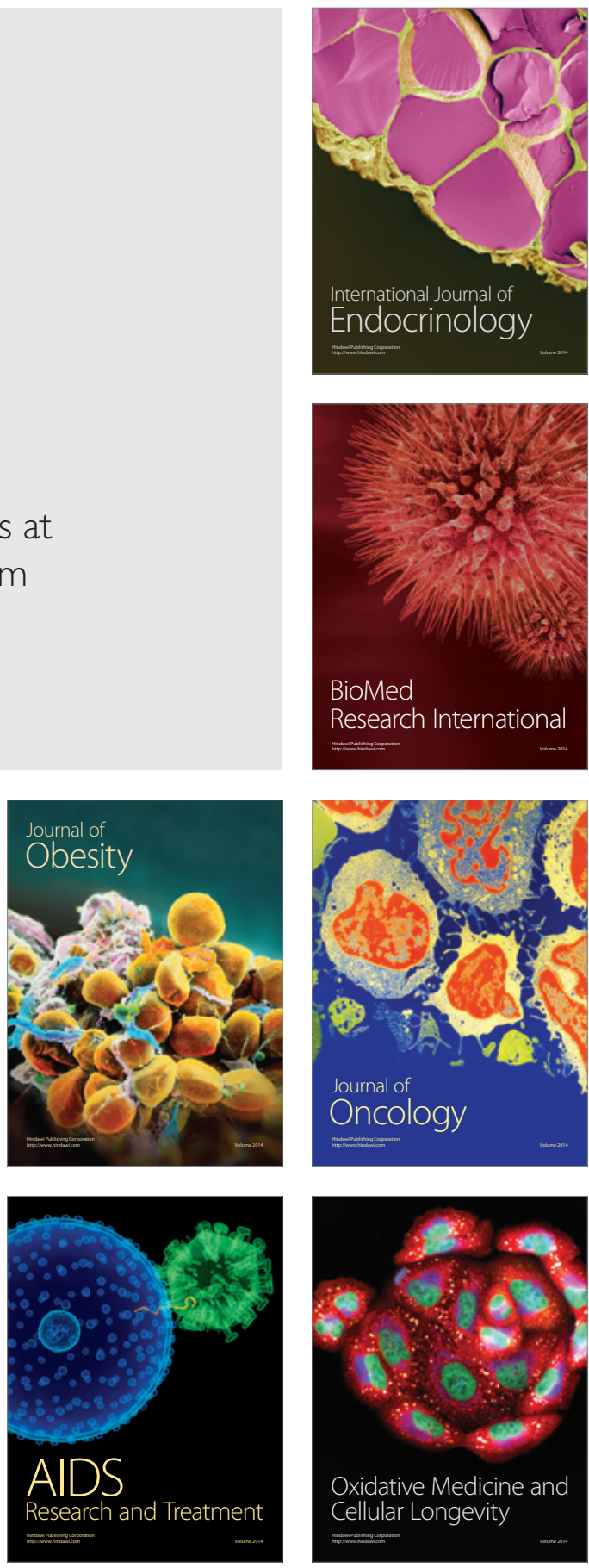